\title{
A Research on some socio-demographic characteristics of companion animal veterinarians and economic structures of companion animal clinics in Istanbul *
}

\section{Canberk BALABAN ${ }^{1^{* *}} \quad$ Halil GÜNEŞ ${ }^{1}$}

\author{
Research Article \\ 1. Istanbul University-Cerrahpaşa, Büyükçekmece Campus, Faculty of Veterinary Medicine, \\ Volume: 5, Issue: 2 \\ August 2021 \\ Department of Animal Breeding and Husbandry, 34500 Büyükçekmece-Istanbul, Turkey. \\ Balaban, C.: ORCID: 0000-0001-7510-7724; Güneş, H.: ORCID: 0000-0002-4154-7104.
}

Pages: $72-86$

\begin{abstract}
Having a pet has become an important phenomenon in recent years and Istanbul stands out as the largest market. The aim of the study is to shine a spotlight on both the veterinarians working in this field and the students who plan to work by examining the economic status of clinics and the socio-demographic structures of veterinarians in Istanbul. Studies were conducted mostly face-to-face in 225 clinics between April 2019 and April 2021. The questionnaires were sent to a small number of veterinarians via e-mail. The first findings were that $42.4 \%$ and $63.6 \%$ of the mean age of the clinicians are male and the majority were Istanbul University graduates with 77.3\%. Vast majority had a negative attitude towards the opening of new faculties $(24.9 \%$ Bad $75.1 \%$ Very Bad), and the majority (79.1\%) had a negative attitude towards the provision of veterinary medicine education in foundation universities. According to the study, for the year 2020 the average monthly earning was 17618 TL (2499 USD) and 28.4\% were less than $10000 \mathrm{TL}$ (1418 USD). The largest income item was vaccination with $28.8 \%$, and the largest expense item was drug expenditures with $23.9 \%$. It had been determined that the average rental price paid was 9569 TL (1357 USD). According to the results, the average annual expenditure was 2822 TL (400 USD) for cats and 4516 TL (641 USD) for dogs. In addition, the annual average uncollectible receivables per clinic has been determined as 28444 TL (4034 USD), which meant a large loss of approximately 21 million TL (approx. 3 million USD) on a provincial basis. In general, the research concluded that veterinarians were satisfied with their professions with deficiencies in basic business information and could spend little time on their social lives due to long hours of work. From this point of view, it is of utmost importance to regulate the working conditions and to increase education programs in business matters during university year and beyond.
\end{abstract}

\section{Article History}

Received: 07.07.2021

Accepted: 03.08.2021

Available online:

25.08.2021
Keywords: veterinary medicine, management, income, cost, economics

DOI: https://doi.org/10.30704/http-www-jivs-net.942018

To cite this article: Balaban, C., Güneş H. (2021). Effects A Research on some socio-demographic characteristics of companion animal veterinarians and economic structures of companion animal clinics in Istanbul . Journal of Istanbul Veterinary Sciences, 5(2), 72-86. Abbreviated Title: J. İstanbul vet. sci.

* This study was prepared from a part of the data obtained from the first author's doctoral thesis titled "Some SocioDemographic Parameters of Companion Animals Veterinary Medicine in Turkey and Technical and Economic Analysis of The Clinics".

\section{Introduction}

The relationship between pets and their owners is both unique and two-way. While their owners give love and compassion to cats and dogs, cats and dogs respond with love, commitment, peace, and health. Studies in this direction have shown that having a pet has many benefits such as increasing the amount of physical activity and accordingly reducing stress (Harvard

**Corresponding Author: Canberk Balaban

E-mail: canberkbalaban@gmail.com
Medical School, 2014), providing an active lifestyle and maintaining a healthy body structure (Ratschen et al., 2020), contributing to the emotional development process with the ability of children to empathize (Vidovic et al., 1999) and reducing the rates of developing certain chronic diseases such as allergic rhinitis (Hesselmar et al., 1999). Due to these and 
some other similar benefits there have been recent increases in cat and dog adoption worldwide, and in parallel with this increase, the pet sector is growing in commercial volume. The commercial volume in the pet sector reached a high point of 223 billion dollars in 2019, and it is seen that the United States has the largest share in this large business volume with 95.8 billion dollars (Global Market Insights, 2020).

The pet sector breaks down into 4 sub-basic groups as Food - Drug/Vaccine - Nutrition Support and Other Services. The biggest share within the categories belongs to pet foods. Drugs and vaccines are in the second place and nutritional support products are in the third place. Other services including training, pension, insurance, etc. are in the fourth place. The structure of the pet industry in the United States also reflects this ranking. Pet food ranks first in the United States market with 39\%. The drugvaccine category ranks second (31\%), nutrient-support products rank third $(20 \%)$ and other services rank fourth (11\%) (APPA, 2020).

The pet sector has also developed in Turkey in recent years in parallel with the development worldwide and has reached a size of approximately 2 billion dollars with an average growth rate of 15\% every year (HEKTAŞ, 2018). In parallel with commercial growth, cat-dog ownership also shows a continuous increase. According to the report published by the European Pet Food Industry Association in 2016, there are 4.3 million owned cats and dogs in Turkey, 3.2 million of which are cats and 1.1 million of which are dogs (FEDIAF, 2016). According to the report in 2020, the total number of cats and dogs reached 5 million, 3.8 million for cats and 1.2 million for dogs (FEDIAF, 2020). As the reports show, the total number of cats and dogs in Turkey increased by $16 \%$ between 2016 and 2020 .

According to the statistics of the Ministry of Agriculture and Forestry, there are a total of 7915 ministry licensed enterprises throughout Turkey (Ministry of Agriculture and Forestry, 2021a), 749 of which are located in Istanbul (Ministry of Agriculture and Forestry, 2021b). Considering that clinics in Istanbul mostly serve companion animals and there are around 1,700 pet clinics in Turkey, the importance of Istanbul for the sector is clearly evident. For this reason, Istanbul province has been selected as the research area.

Although pet clinics were established mainly to provide diagnostic, treatment and care services, they are also commercial enterprises and establishing a business has economic and social purposes such as having an independent business, providing profit, serving the consumer and the public, and reducing unemployment (Kaygısız and Akdağ, 2004). For this reason, this study aims to analyse the sociodemographic characteristics of veterinarians working on companion animals in Istanbul and to evaluate the economic structures of the clinics with various parameters.

\section{Materials and Method}

The material of the research consists of the data collected and processed in computer environment through a questionnaire from veterinary clinics working exclusively for companion animals established in Istanbul.

Simple Random Sampling method was used in the selection of clinics to be surveyed. Simple random sampling is the selection of an " $n$ " unit sample from an " $N$ " unit main mass by giving an equal chance to all $" n$ " unit samples (Orhunbilge, 2000). In this study, in random selection, the main mass is considered as a whole and is not divided into a certain group and clusters. Sample size represents around $30 \%$ of respective market.

Microsoft Office Excel 2010 and IBM SPSS Statistics 22 for Windows programs were used for data processing and analysis, and since the study is descriptive, the results are presented as frequency distribution, ratios, and graphics.

In the analysis of the survey results, arithmetic mean method was used in general. Before calculating the averages of the answers to the grouped questions, frequency tables were created and their averages were calculated over the frequencies with the midpoints of the ranges. The incidence of an observation value or measurement result within observation units is determined as the frequency of this value. In frequency tables, frequencies for one or several variables are presented in a structured manner (Evrim and Güneş, 2000; Demir, 2017).

While converting all respective data from Turkish Lira to United States Dollar The Central Bank of the Republic of Turkey records were used. Average USD foreign exchange rate was 7,05 TL during the period that study was conducted, between April 2019 - April 2021.

\section{Results}

Using the data obtained from 225 pet veterinary clinics in Istanbul participating in the study, the findings are given below in titles according to the subjects examined in the questionnaire. 
1. Age distribution: Within the scope of the study, the average age of veterinarians working for companion animals in Istanbul was calculated as 42.4 years old; the youngest veterinarian was 25 years old and the oldest veterinarian was 60 years old.

Table 1. Average age of veterinarians in Istanbul (Year)

\begin{tabular}{cccccc}
\hline$n$ & Mean & SD & Min. & Max. & Med. \\
\hline 225 & 42.4 & 7.17 & 25.0 & 60.0 & 43.0 \\
\hline
\end{tabular}

SD = Standard deviation, Min = Minimum, Max = Maximum Med $=$ Median

Table 2. Age groups and distribution of veterinarians

\begin{tabular}{lcc}
\hline Age Range & Frequency & Percent (\%) \\
\hline Age $25-30$ & 13 & 5.8 \\
Age $31-40$ & 60 & 26.7 \\
Age $41-50$ & 126 & 56.0 \\
Age 51 and above & 26 & 11.5 \\
\hline
\end{tabular}

2. Gender distribution: According to results, $63.6 \%$ of the veterinarians in the participating clinics are male and $36.4 \%$ are female.

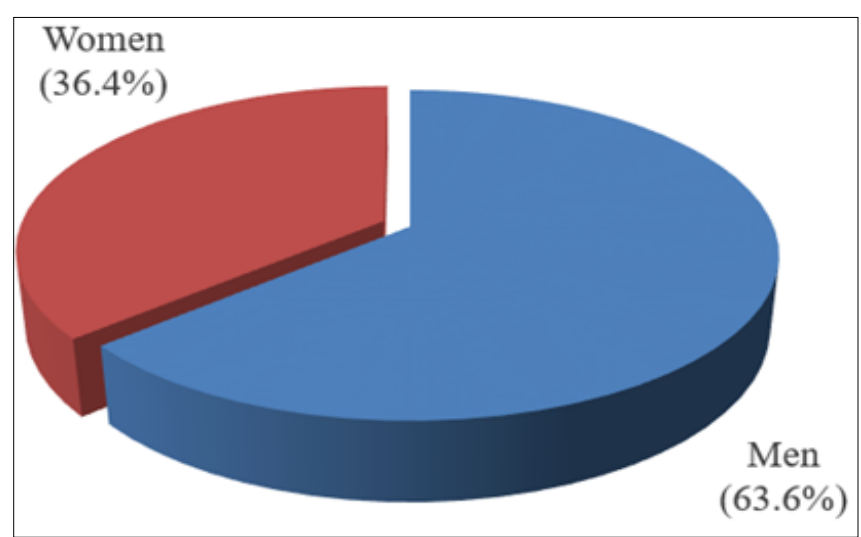

Figure 1. Gender distribution of veterinarians.

3. Marital status: According to results, $88.9 \%$ of the veterinarians participating in the study are married and $11.1 \%$ are single.

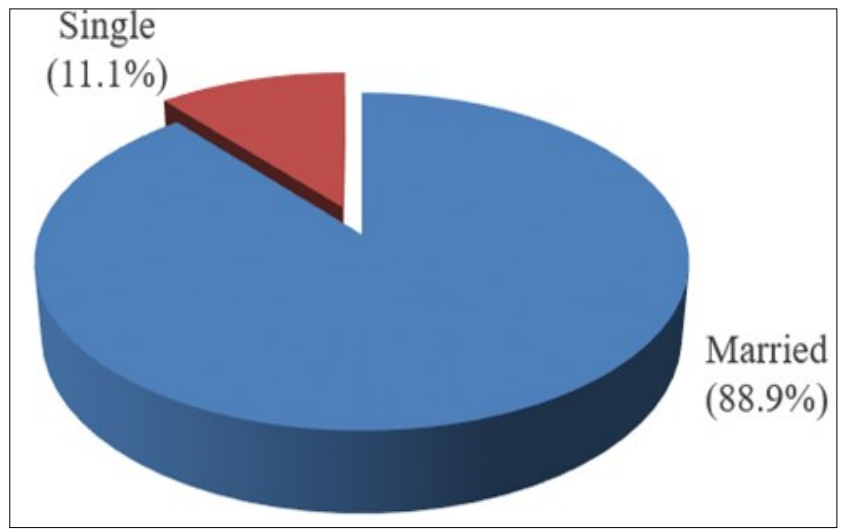

Figure 2. Marital status of veterinarians.
4. University status: Data obtained shows that $77.3 \%$ of the veterinarians who participated in the study and worked in the clinics in Istanbul are graduates of Istanbul University. Ankara University ranks second with $11.6 \%$.

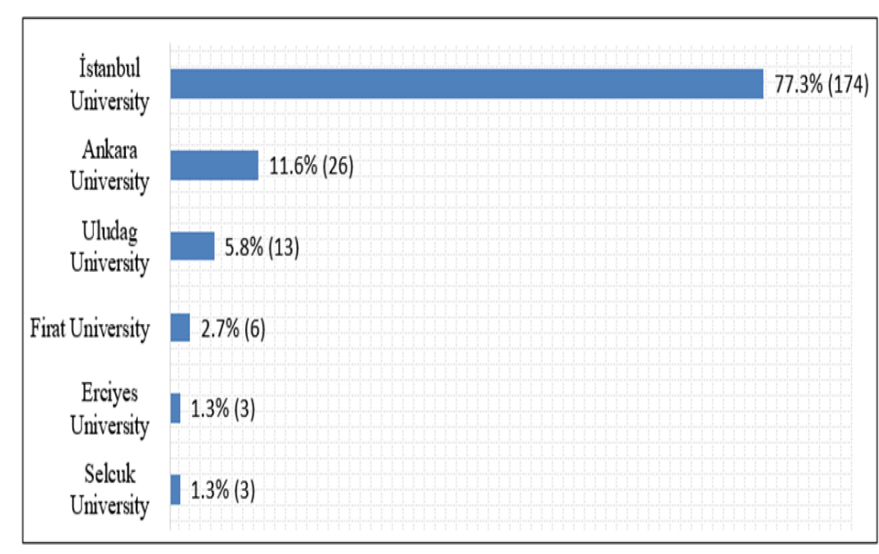

Figure 3. University status.

5. Experience status: The average duration of experience of the veterinarians participating in the study was found to be 17.1 years. The least experienced veterinarian has been in the profession for 3 years and the most experienced veterinarian has been in the profession for 35 years.

Table 3. Experience status of veterinarians (Year).

\begin{tabular}{cccccc}
\hline$n$ & Mean & SD & Min. & Max. & Med. \\
\hline 225 & 17.1 & 7.68 & 3.0 & 35.0 & 18.0 \\
\hline
\end{tabular}

$\mathrm{SD}=$ Standard deviation, Min = Minimum, Max $=$ Maximum Med $=$ Median

Table 4. Experience groups of veterinarians (Year).

\begin{tabular}{lcc}
\hline Experience & Frequency & $\begin{array}{c}\text { Percent } \\
(\%)\end{array}$ \\
\hline 0-5 years & 20 & 8.9 \\
6-10 years & 38 & 16.9 \\
11-20 years & 94 & 41.8 \\
20-30 years & 68 & 30.2 \\
31 years and more & 5 & 2.2 \\
\hline
\end{tabular}

6. Educational status : According to results, $84.9 \%$ of the veterinarians who participated in the study completed their faculty, $14.2 \%$ completed their doctoral education, and $0.9 \%$ started working in the clinic after their academic studies. 
Table 5. Educational groups and distribution of veterinarians.

\begin{tabular}{lcc}
\hline Educational Status & Frequency & Percent (\%) \\
\hline DVM & 191 & 84.9 \\
Doctorate & 32 & 14.2 \\
Academician & 2 & 0.9 \\
\hline
\end{tabular}

7. In which order the faculty they graduated is seen : Results shows that $16.9 \%$ of the veterinarians who participated in the study stated that they evaluated the faculty they graduated from at the top, $31.5 \%$ above the middle and $37.8 \%$ at the highest level.

Table 6. In which order the graduated faculty is seen

\begin{tabular}{lccc}
\hline Order & Frequency & $\begin{array}{c}\text { Percent } \\
(\%)\end{array}$ & $\begin{array}{c}\text { Cumulative } \\
\text { Percent (\%) }\end{array}$ \\
\hline At the top & 38 & 16.9 & 16.9 \\
Above Middle & 71 & 31.5 & 48.4 \\
Middle & 85 & 37.8 & 86.2 \\
Below Middle & 31 & 13.8 & 100.0 \\
Total & 225 & 100.0 & \\
\hline
\end{tabular}

8. Recommendation status of the faculty they graduated : According to data obtained $56.5 \%$ of the veterinarians who participated in the study stated that they recommended the faculty they graduated from and $17.3 \%$ stated that they would not recommend it.

Table 7. Recommendation status of faculty they graduated

\begin{tabular}{lccc}
\hline Recommendation & Frequency & $\begin{array}{c}\text { Percent } \\
(\%)\end{array}$ & $\begin{array}{c}\text { Cumulative } \\
\text { Percent (\%) }\end{array}$ \\
\hline Yes & 127 & 56.5 & 56.5 \\
No & 39 & 17.3 & 73.8 \\
Undecided & 59 & 26.2 & 100.0 \\
Total & 225 & 100.0 & \\
\hline
\end{tabular}

9. Communication status of with the academic members and assistants of the faculty : According to results, $16.0 \%$ of the veterinarians who participated in the study stated that they were in constant communication with the faculty members and assistants in the faculty they graduated from, and some of them $(16.4 \%)$ stated that they had no communication at all (Table 8).
Table 8. Communication status of with the academic members and assistants of the faculty.

\begin{tabular}{lccc}
\hline Contact & Frequency & $\begin{array}{c}\text { Percent } \\
(\%)\end{array}$ & $\begin{array}{c}\text { Cumulative } \\
\text { Percent (\%) }\end{array}$ \\
\hline Continuous & 36 & 16.0 & 16.0 \\
Occasionally & 61 & 27.1 & 43.1 \\
Rarely & 91 & 40.5 & 83.6 \\
Never & 37 & 16.4 & 100.0 \\
Total & 225 & 100.0 & \\
\hline
\end{tabular}

10. Thoughts on the impact of increasing the number of faculties on the quality of education : Results show that $24.9 \%$ of the veterinarians participating in the study stated that opening new faculties would be a

Table 9. The impact of increasing the number of faculties on the quality of education.

\begin{tabular}{lcc}
\hline Impacts & Frequency & $\begin{array}{c}\text { Percent } \\
(\%)\end{array}$ \\
\hline Very Good & 0 & 0 \\
Good & 0 & 0 \\
Poor & 56 & 24.9 \\
Very Poor & 169 & 75.1 \\
Neutral & 0 & 0 \\
Total & 225 & 100.0 \\
\hline
\end{tabular}

bad improvement on the quality of education and $75.1 \%$ stated that it would be a very bad development (Table 9).

11. Thoughts on the impact of opening faculties in foundation Universities on quality of education : According to results, $16.9 \%$ of the veterinarians

Table 10. Impact of opening faculties in foundation universities on the quality of education.

\begin{tabular}{lccc} 
Impacts & Frequency & $\begin{array}{c}\text { Percent } \\
(\%)\end{array}$ & $\begin{array}{c}\text { Cumulative } \\
\text { Percent (\%) }\end{array}$ \\
\hline Very Good & 0 & 0 & 0 \\
Good & 4 & 1.8 & 1.8 \\
Poor & 38 & 16.9 & 18.7 \\
Very Poor & 178 & 79.1 & 97.8 \\
Neutral & 5 & 2.2 & 100.0 \\
Total & 225 & 100.0 & \\
\hline
\end{tabular}

participating in the study stated that opening new faculties in foundation universities would be a bad development and $79.1 \%$ stated that it would be a very bad development. 
12. Willingness to work in a pet clinic before study stated that they started their first job with graduation : According to data obtained $78.7 \%$ of the chambers' minimum wage after graduation. veterinarians participating in the study stated that they wanted to work on companion animals before graduating from the faculty.

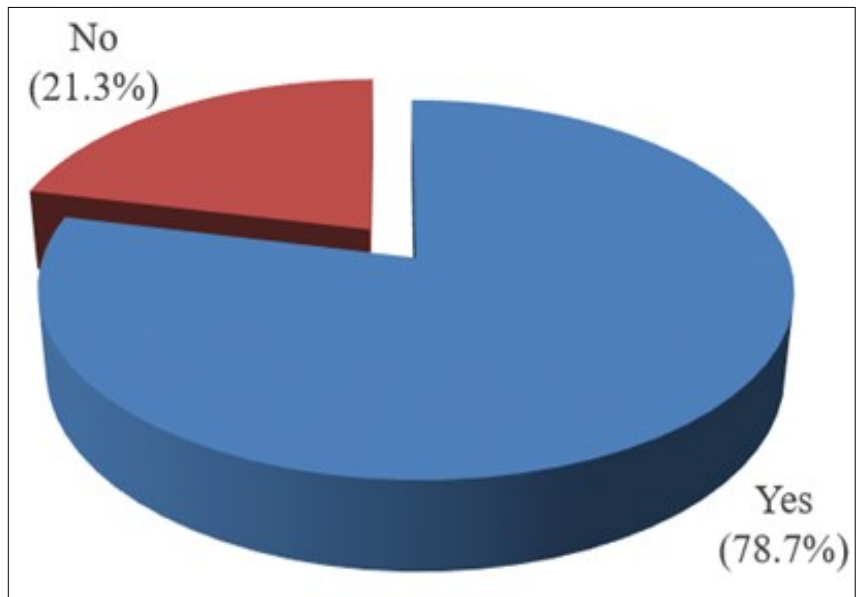

Figure 4. Willingness to work in a pet clinic before graduation.

13. The first sector after graduation: Results show that $68.0 \%$ of the veterinarians who participated in the study stated that they started working in the pet clinic after graduation.

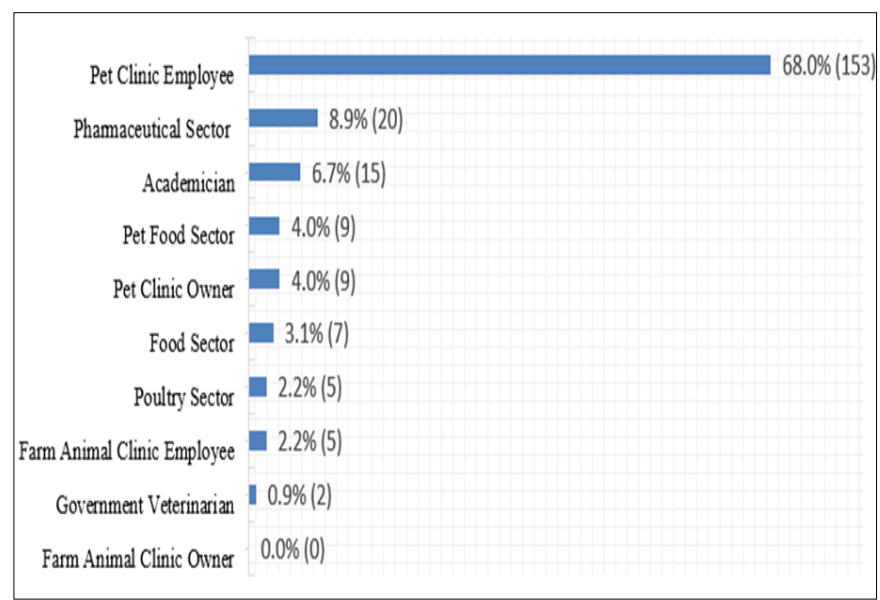

Figure 5. The first sector after graduation.

14. Initial employment time after graduation : As a result of the research, it was determined that veterinarians started working 3.8 months after graduation on average.

Table 11. Initial employment time after graduation (Month).

\begin{tabular}{cccccc}
\hline$n$ & Mean & SD & Min. & Max. & Med. \\
\hline 225 & 3.8 & 5.27 & 0 & 48 & 2.00
\end{tabular}

$\mathrm{SD}=$ Standard deviation, Min = Minimum, Max = Maximum Med $=$ Median

15. Wage on the first employment: It was determined that $70.2 \%$ of the veterinarians who participated in the
Table 12. Wage on the first employment.

\begin{tabular}{lccc}
\hline First salary & Frequency & $\begin{array}{c}\text { Percent } \\
(\%)\end{array}$ & $\begin{array}{c}\text { Cumulative } \\
\text { Percent (\%) }\end{array}$ \\
\hline $\begin{array}{l}\text { Chamber Minimum } \\
\text { Wage }\end{array}$ & 158 & 70.2 & 70.2 \\
$\begin{array}{l}\text { Double/Twice Chamber } \\
\text { Minimum wage }\end{array}$ & 44 & 19.6 & 89.8 \\
More & 23 & 10.2 & 100.0 \\
Total & 225 & 100.0 & \\
\hline
\end{tabular}

16. Job satisfaction status : The majority of veterinarians who participated in the study stated that they were satisfied with their profession. Only $3.1 \%$ said they were dissatisfied.

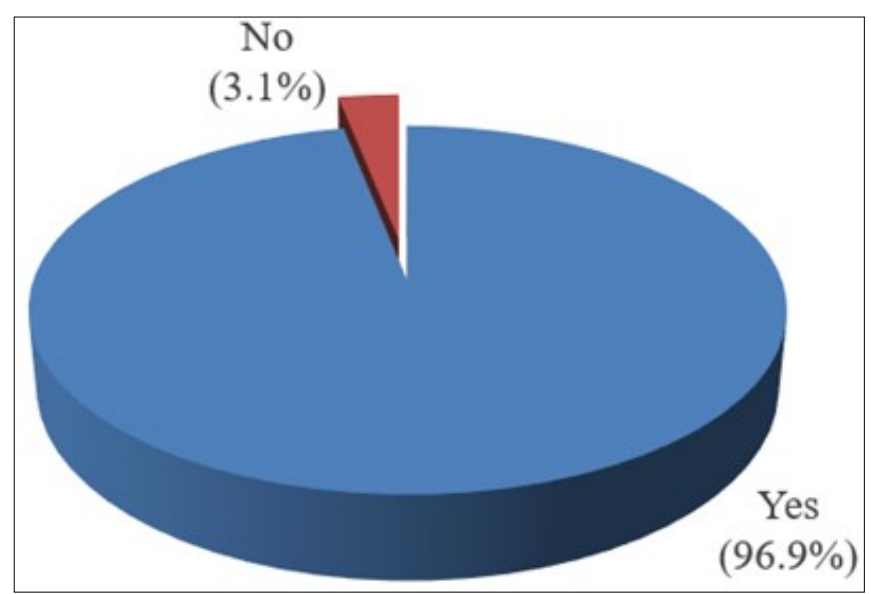

Figure 6. Job satisfaction status -general.

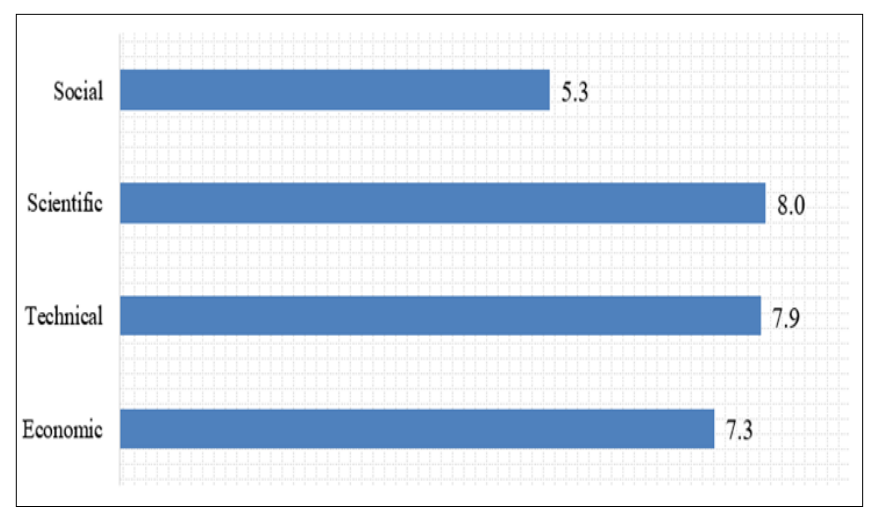

Figure 7. Job satisfaction status of veterinarians Satisfaction level over 10 points

17. Status of recommending veterinary medicine : The vast majority of veterinarians who participated in the study reported that they recommended being veterinarian. 


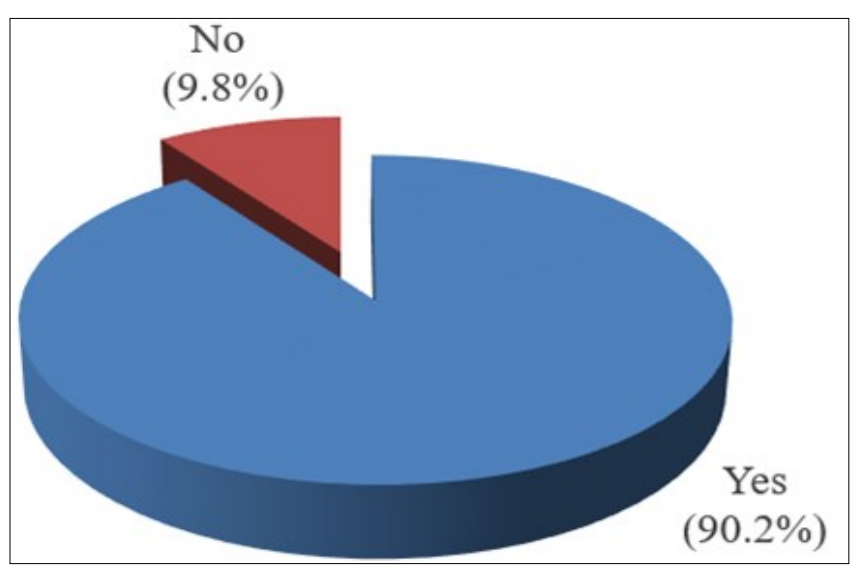

Figure 8: Status of recommending veterinary medicine

18. Status of recommending veterinary medicine for companion animals :Results show that $79.1 \%$ of the veterinarians participating in the study reported that they recommended being companion animal clinician.

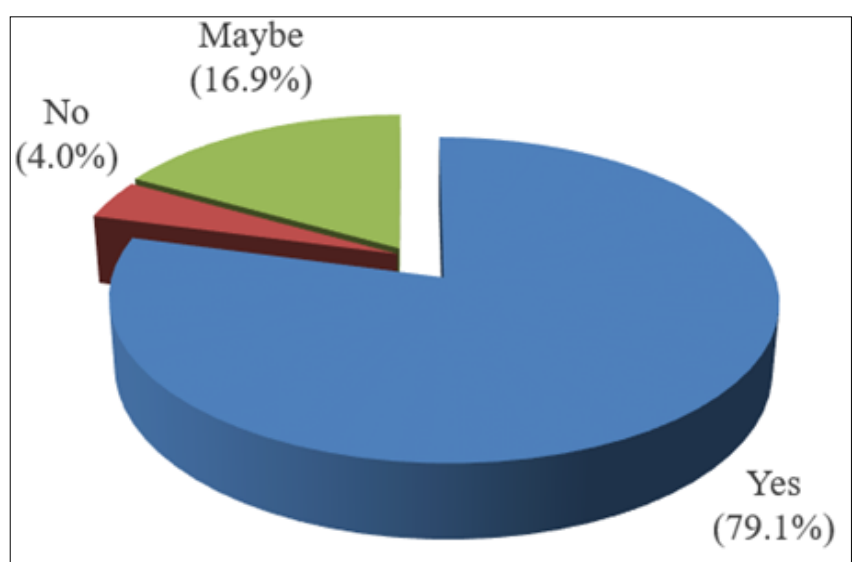

Figure 9: Status of recommending veterinary medicine for companion animals.

19. Reason for choosing veterinary medicine : According to results $68.9 \%$ of the participants stated that they chose veterinary medicine due to job satisfaction.

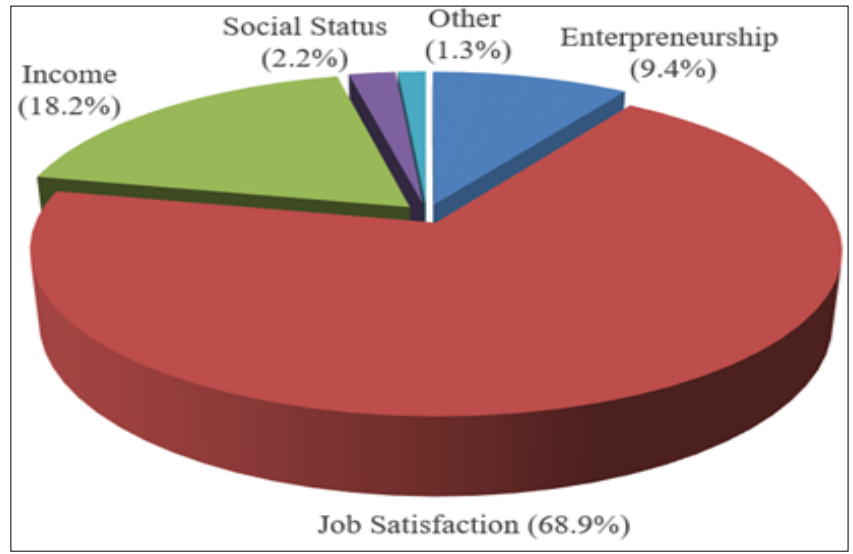

Figure 10. Reason for choosing veterinary medicine
20. Reason for choosing to work as companion animal clinician in veterinary medicine profession : It was determined that $57.4 \%$ of the veterinarians who participated in the study reported that they chose this form of work because they wanted to be a pet clinician.

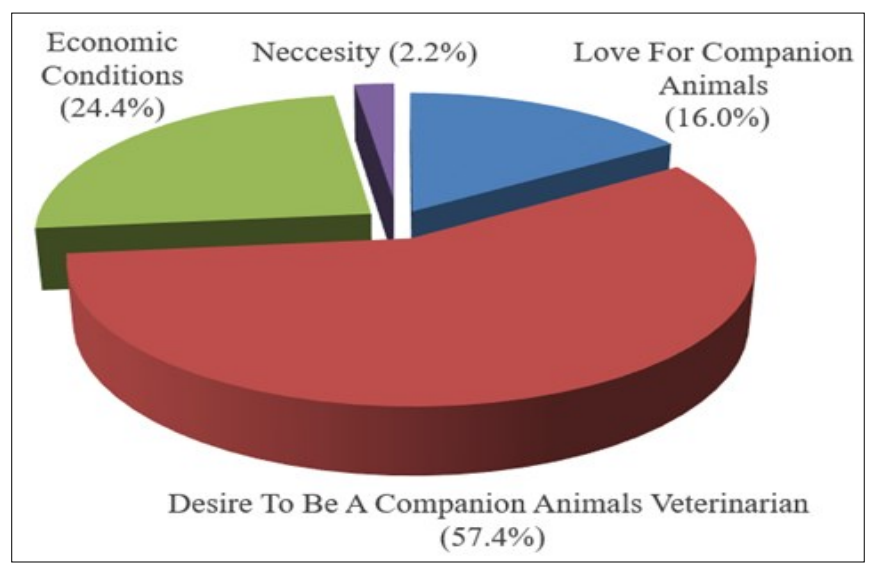

Figure 11. Reason for choosing companion animal clinician in veterinary medicine.

21. Status of choosing veterinary medicine again in occupational selection : Results show that $76.4 \%$ of the veterinarians who participated in the study stated that they would choose veterinary medicine again as a profession if they had to make a decision now.

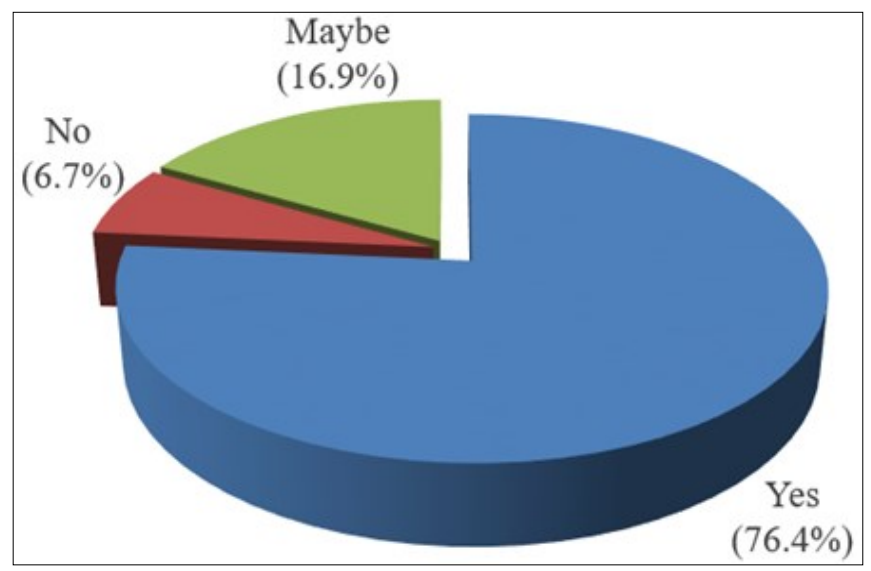

Figure 12. Status of choosing veterinary medicine again in occupational selection.

22. Daily working hours : The average daily working hours of the veterinarians participating in the study is 10.5 hours.

Table 13. Daily working hours.

\begin{tabular}{cccccc}
\hline$n$ & Mean & SD & Min. & Max. & Med. \\
\hline 225 & 10.5 & 1.33 & 7.0 & 12.0 & 10.00 \\
\hline
\end{tabular}


23. Being able to spare time to private life : Only $7.6 \%$ of the veterinarians who participated in the study stated that they could always spare enough time for their private lives, while $33.3 \%$ stated that they could not spare any time.

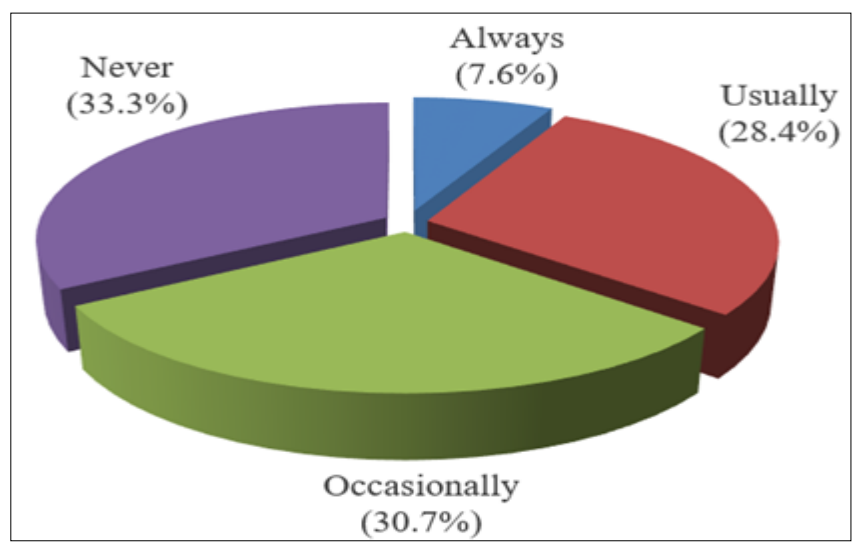

Figure 13. Being able to spare time to private life.

24. Solidarity with other veterinarians and clinics in the region : According to results, $57.7 \%$ of the veterinarians participating in the study stated that there was a weak solidarity between other clinics and veterinarians.

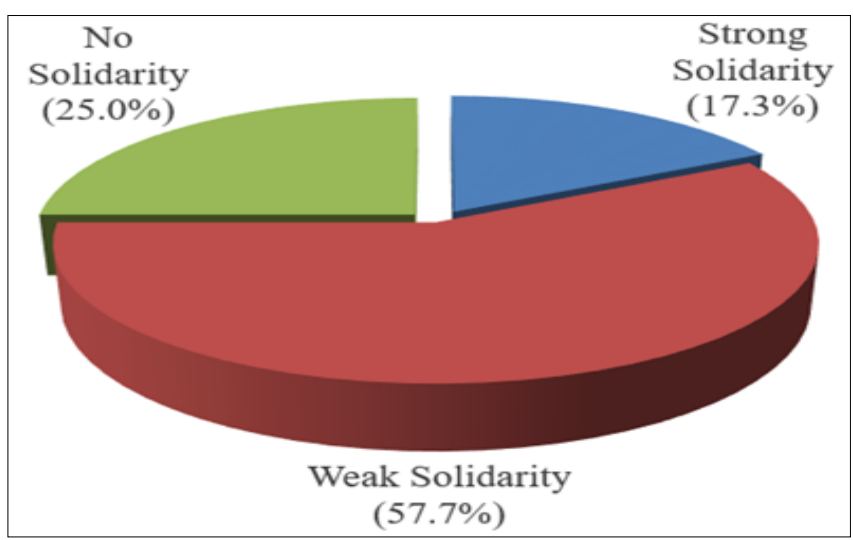

Figure 14. Solidarity status.

25. Future status of veterinary medicine : Results show that $40.9 \%$ of the veterinarians who participated in the study stated that the status of the profession would be moderate in the future.

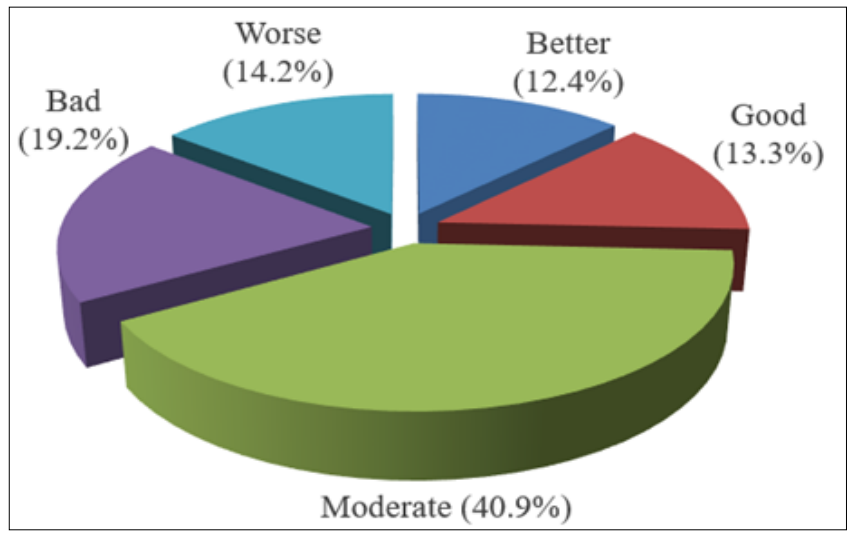

Figure 15. Future status of veterinary medicine.
26. Participation in occupational organizations : According to data obtained $78.2 \%$ of the veterinarians participating in the study stated that they participated in the organizations held. The most frequently attended organizations are organized by associations with 33.0\%.

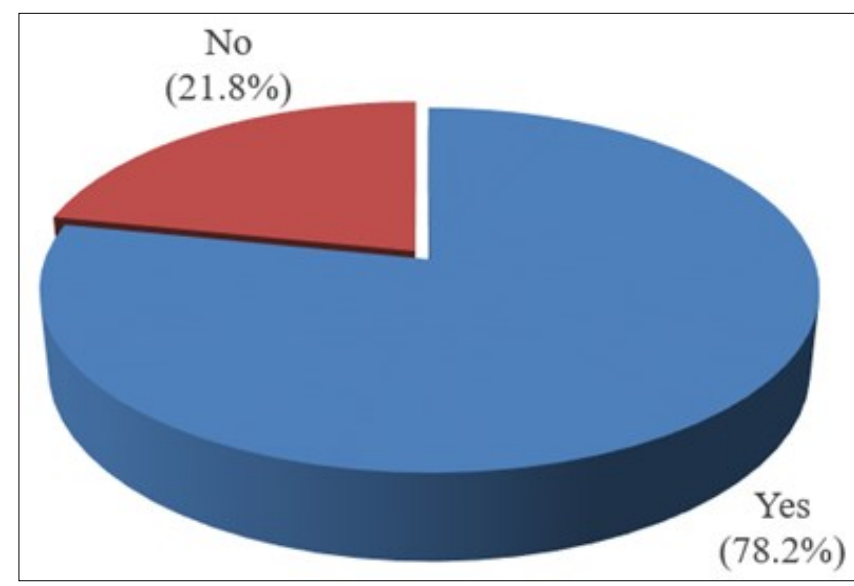

Figure 16. Participation in occupational organizations Figure 17. Distribution of participation in organizations held.

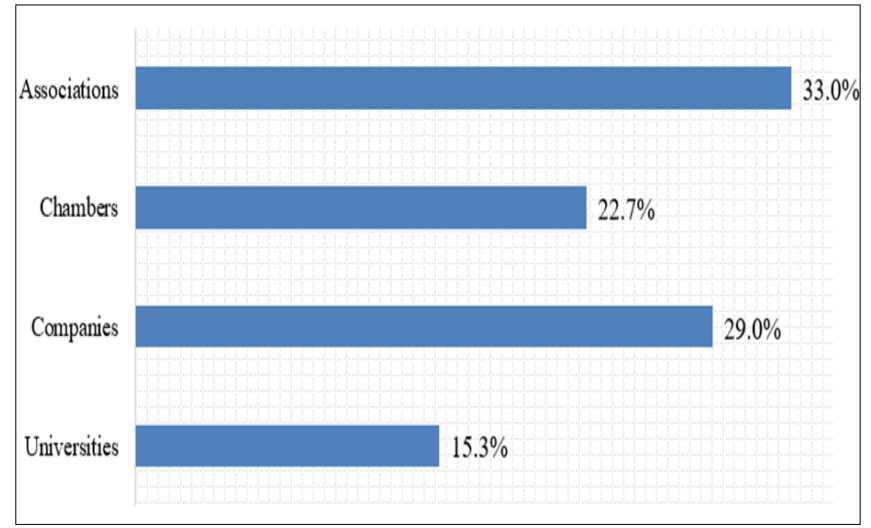

27. Benefits of occupational organizations : Results show that $50.4 \%$ of the veterinarians participating in the study stated that they think that the most important benefit of the occupational organizations is occupational education.

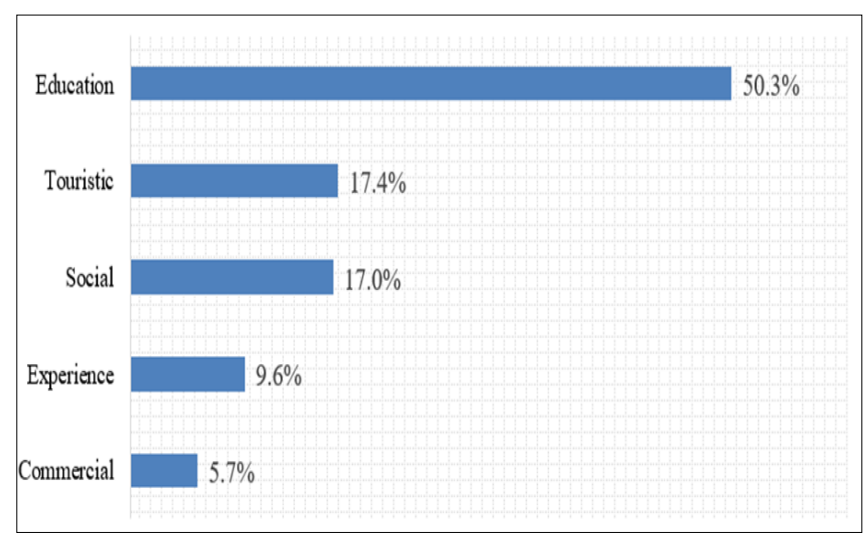

Figure 18. Benefits of occupational organizations. 
28. Scientific and professional publications followed regularly : Only $17.8 \%$ of the veterinarians participating in the study stated that they regularly follow scientific or professional publications.

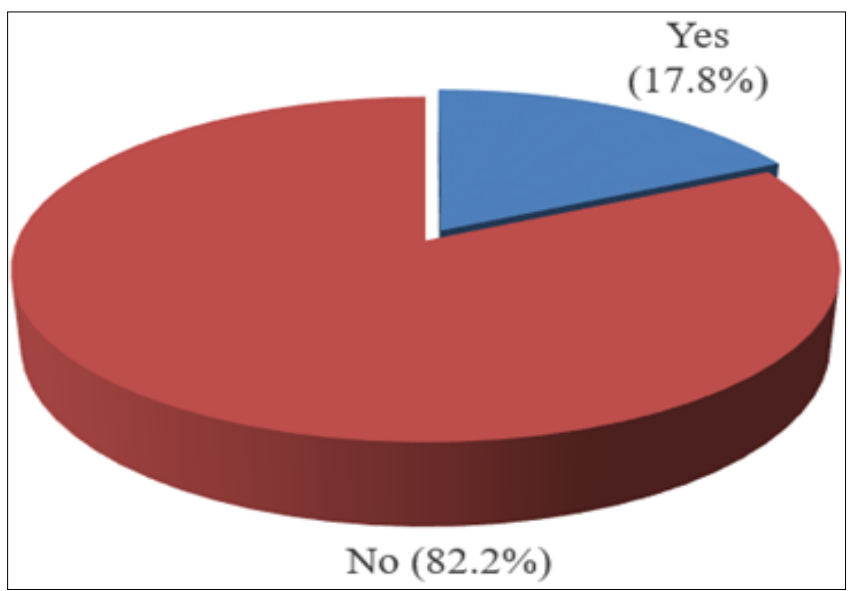

Figure 19. Regular scientific and professional publication follow-up rate.

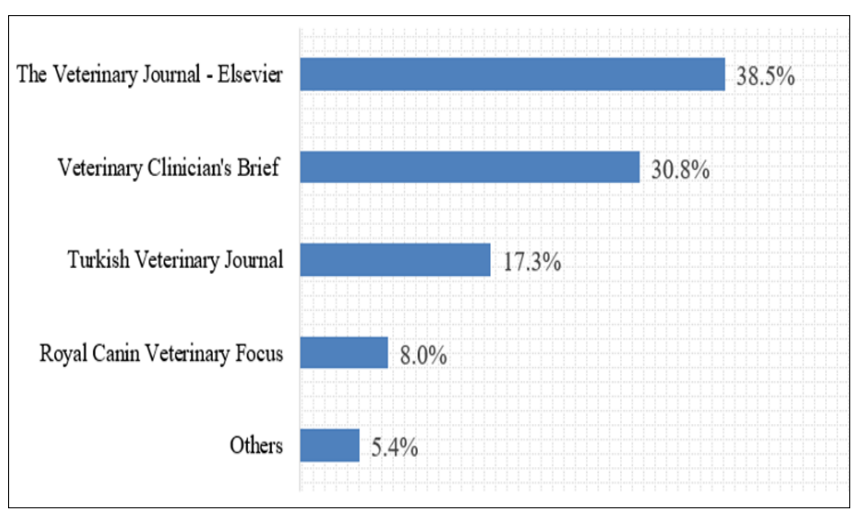

Figure 20. Distribution of regularly followed scientific and professional publications.

29. Number of employees: As a result of the study, it was determined that an average of 2.3 veterinarians and 0.8 veterinary technicians/technicians worked in the clinics. Average total number of employees is 4.8 .

Table 14. Number of employees.

\begin{tabular}{lcccccc}
\hline Group & $n$ & Mean & SD & Min. & Max. & Med. \\
\hline Veterinarian & 225 & 2.3 & 1.55 & 1.0 & 9.0 & 2.0 \\
Technician & 225 & 0.8 & 0.85 & 0.0 & 4.0 & 1.0 \\
Total & 225 & 4.8 & 4.29 & 1.0 & 25.0 & 4.0 \\
\hline
\end{tabular}

$\mathrm{SD}=$ Standard deviation, Min = Minimum, Max = Maximum Med $=$ Median

30. Service status outside the clinic: At the end of the study, it was determined that $69.8 \%$ of the clinics also served outside the clinic.

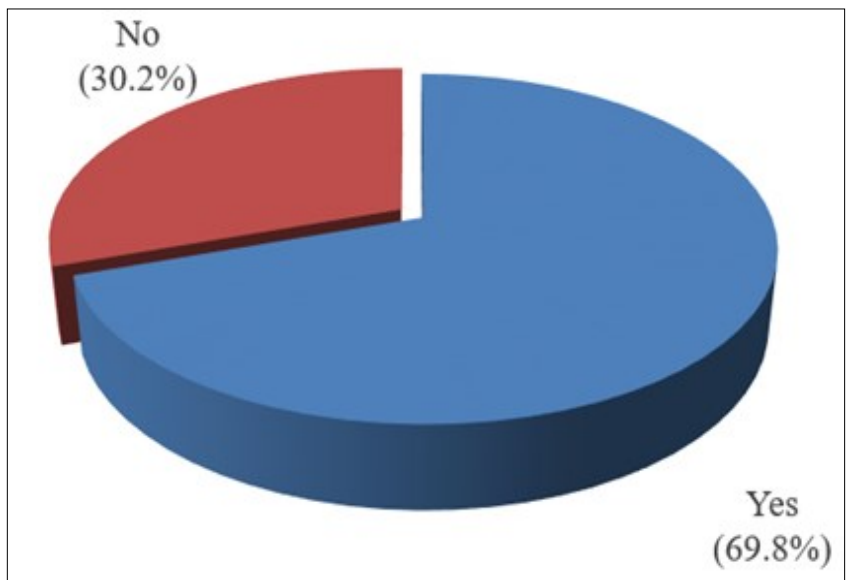

Figure 21. Service status outside the clinic.

31. Preferability criteria of clinics : According to results $66.7 \%$ of the veterinarians participating in the study stated that the criterion that the patient owners attach the most importance to when choosing clinics was the reference. The closeness of the clinic is the second criterion with a rate of $20.4 \%$.

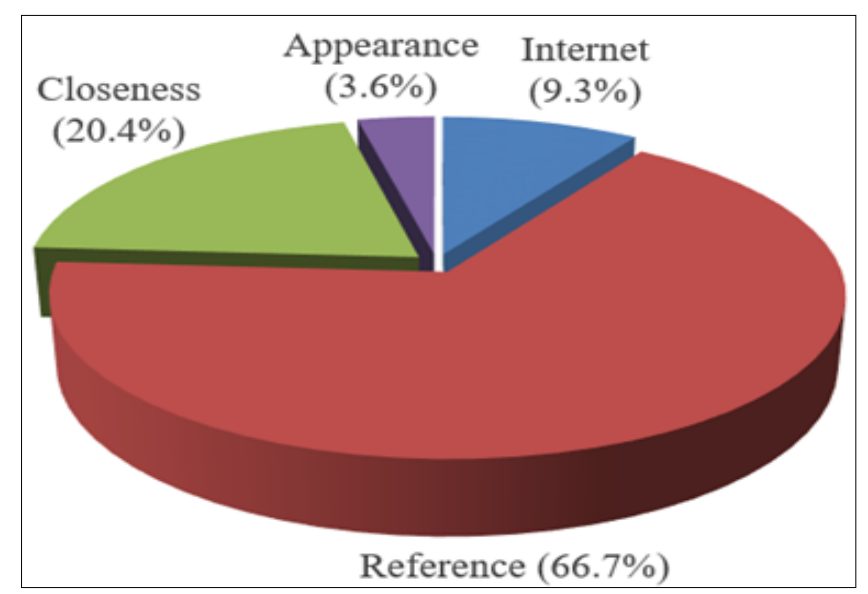

Figure 22. Preferability criteria of clinics.

32. Annual expenditure amounts of patients: The veterinarians who participated in the study stated that the average annual expenditure of the patients was 2822 TL (400 USD) for cats and 4516 TL (641 USD) for dogs

Table 15. Annual expenditures of patients brought to the clinic (TL).

\begin{tabular}{lcccccc} 
Group & $n$ & Mean & SD & Min. & Max. & Med. \\
\hline Cat & 225 & 2822 & 611.9 & 1500 & 5000 & 2500 \\
Dog & 225 & 4516 & 967.5 & 2500 & 7000 & 4500
\end{tabular}

$\mathrm{SD}=$ Standard deviation, Min = Minimum, Max = Maximum Med $=$ Median .

Average USD FX rate was 7,05 TL during the period that study was conducted. 
33. Monthly net earnings: The average monthly earnings of the veterinarians participating in the study were calculated as 17618 TL (2499 USD). In this study reported $86.7 \%$ of veterinarians an average monthly income of less than 30000 TL (426 USD).

Table 16. Monthly net earnings (TL).

\begin{tabular}{lcccc}
\hline Income Range & Frequency & $\begin{array}{c}\text { Percent } \\
(\%)\end{array}$ & Median & $\begin{array}{c}\text { Frequency* } \\
\text { Median }\end{array}$ \\
\hline $0-10000$ & 64 & 28.4 & 5000 & 320000 \\
$11000-20000$ & 67 & 29.9 & 15000 & 1005000 \\
$21000-30000$ & 64 & 28.4 & 25000 & 1600000 \\
$31000-40000$ & 20 & 8.9 & 35000 & 700000 \\
$41000-+$ & 10 & 4.4 & 45000 & 450000 \\
Average Monthly Earnings & & 17618 & \\
\hline
\end{tabular}

Average USD FX rate was 7,05 TL during the period that study was conducted.

34. Monthly average rent paid : With the study, it was determined that 217 of 225 clinics paid an average monthly rent of 9569 TL (1357 USD) to their clinics as lessee.

Table 17. Monthly average paid rent (TL).

\begin{tabular}{lcccc}
\hline Rental Range & Frequency & $\begin{array}{c}\text { Percent } \\
(\%)\end{array}$ & Median & $\begin{array}{c}\text { Frequency* } \\
\text { Median }\end{array}$ \\
\hline $0-5000$ & 54 & 24.9 & 2500 & 135000 \\
$6000-10000$ & 106 & 48.8 & 8000 & 848000 \\
$11000-20000$ & 44 & 20.3 & 15500 & 682000 \\
$21000-30000$ & 5 & 2.3 & 25500 & 127500 \\
$31000-40000$ & 8 & 3.7 & 35500 & 284000 \\
Average Month Lease & & 9569 & \\
\hline
\end{tabular}

Average USD FX rate was 7,05 TL during the period that study was conducted

35. Distribution of income and expense items : The clinics participating in the study reported that the biggest income item was vaccination applications $(28.8 \%)$ and the biggest expense item was medicine expenses (23.9\%).

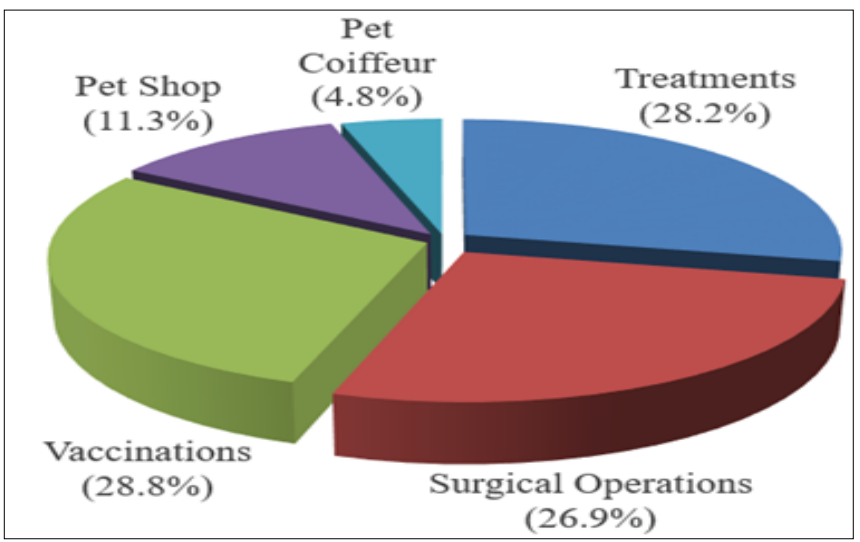

Figure 23. Distribution of income items.

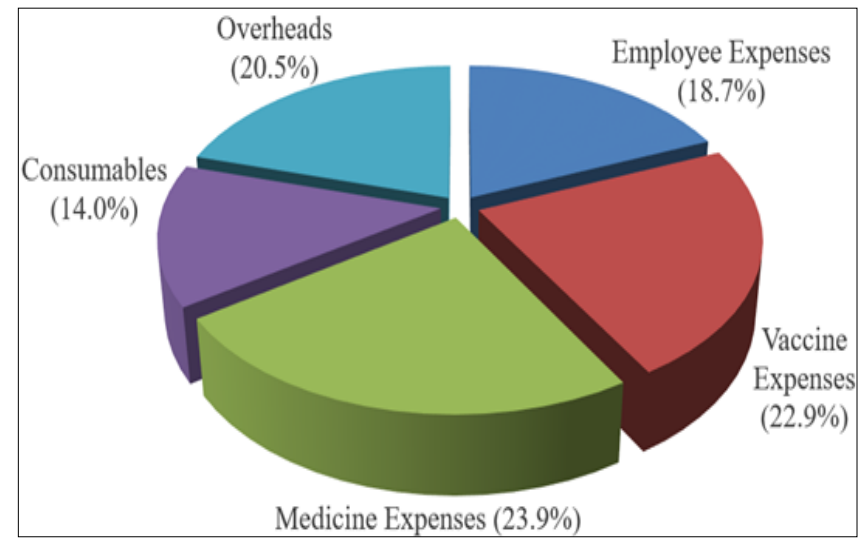

Figure 24. Distribution of expense items.

36. Medical devices in the clinic and total value : As a result of the research, it was determined that all clinics had microscopic examination set and $95 \%$ had $\mathrm{X}$-ray units. The average value of medical devices in clinics is 287422 TL (40770 USD).

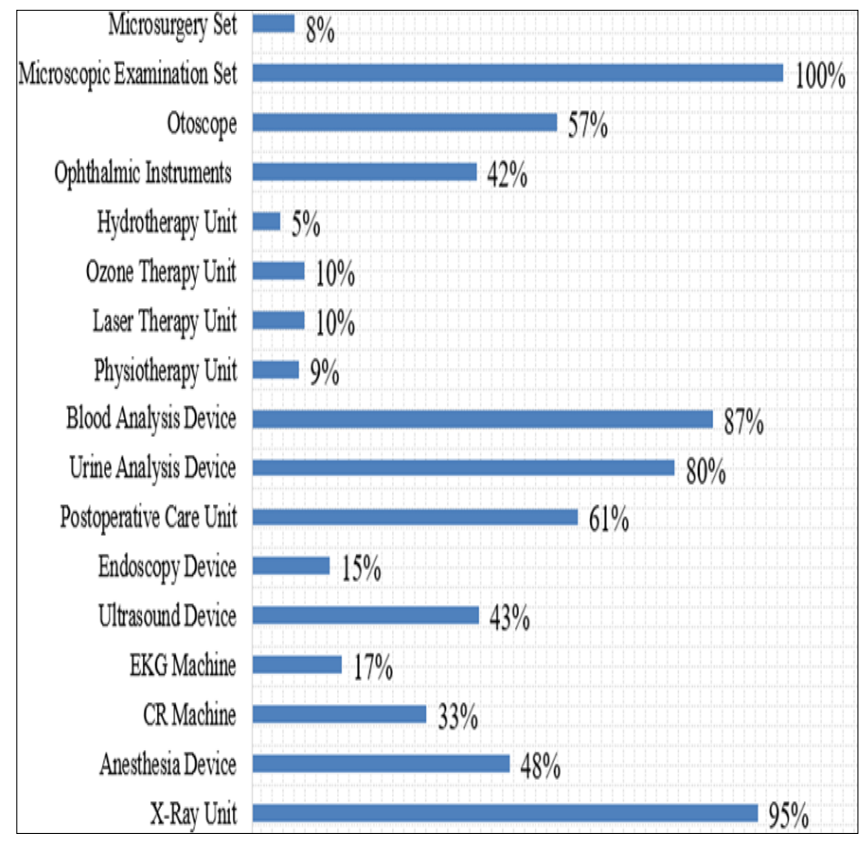

Figure 25. Ratios of medical devices found in clinics.

Table 18. Total value of medical devices in clinics (TL).

\begin{tabular}{cccccc}
\hline$n$ & Mean & SD & Min. & Max. & Med. \\
\hline 225 & 287422 & 351904.9 & 75000 & 2500000 & 200000
\end{tabular}

$\mathrm{SD}=$ Standard deviation, Min = Minimum, Max = Maximum Med $=$ Median .

Average USD FX rate was 7,05 TL during the period that study was conducted.

37. Rental medical device status : It has been determined that only $2.0 \%$ of the clinics have medical devices for hire. 


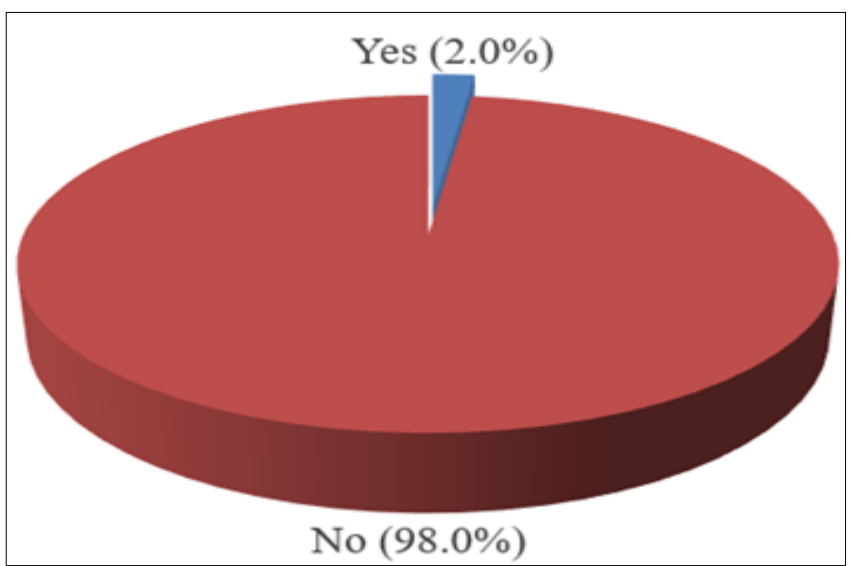

Figure 26. Rental medical device status.

38. Collection status of the requested fee for the service provided : The veterinarians who participated in the study reported that $73.0 \%$ of them usually collected the fee they demanded for the service they provided.

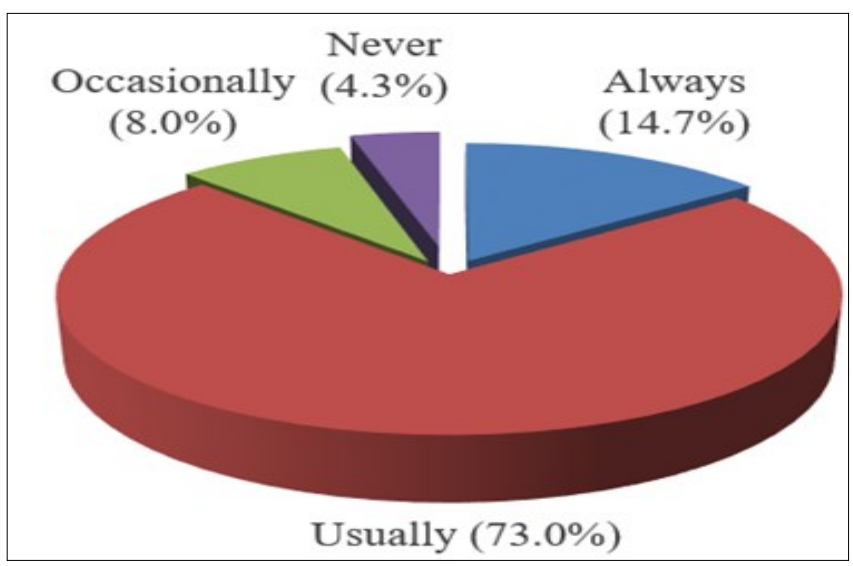

Figure 27. Collection status of the requested fee

39. Payment and collection method preferences : With the research, it was determined that the clinics made their payments with a credit card at the rate of $47.2 \%$ and their receivables were collected with a credit card at the rate of $73.9 \%$.

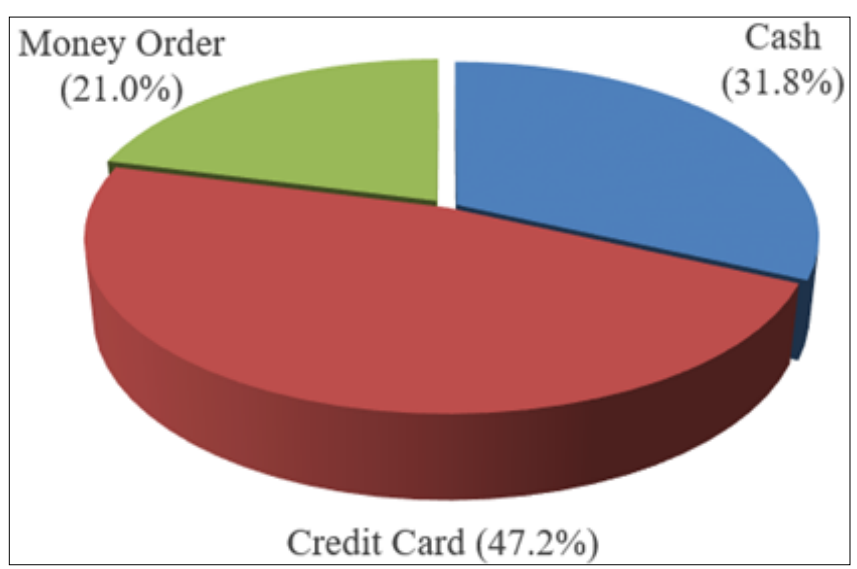

Figure 28. Payment methods.

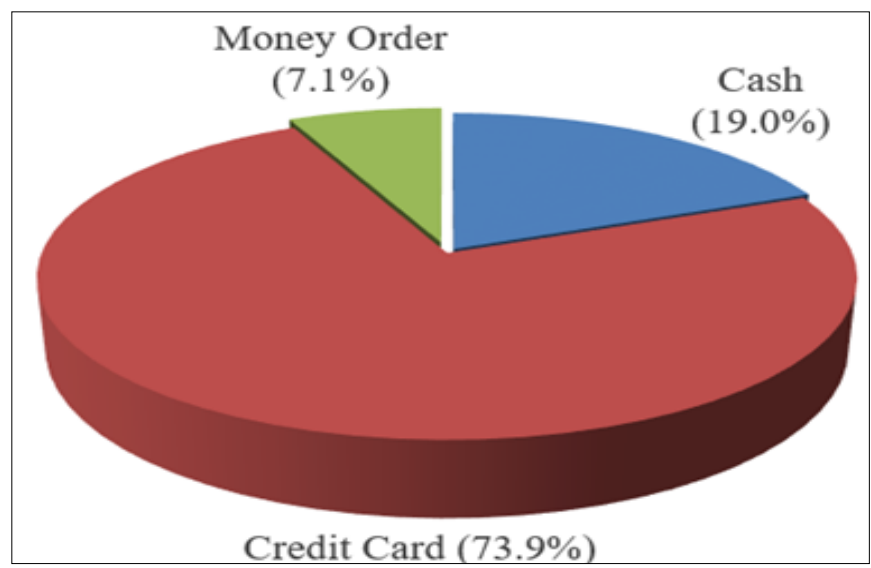

Figure 29.Collection methods.

40. Uncollected receivables : With the research, it has been determined that clinics have uncollected receivables of 28444 TL (4034 USD) on average annually.

Table 19. Average annual amount of uncollected receivables (TL).

\begin{tabular}{cccccc}
\hline$n$ & Mean & SD & Min. & Max. & Med. \\
\hline 225 & 28444 & 19388.6 & 0 & 80000 & 25000 \\
\hline
\end{tabular}

$\mathrm{SD}=$ Standard deviation, Min = Minimum, Max = Maximum Med $=$ Median .

Average USD FX rate was 7,05 TL during the period that study was conducted.

\section{Discussion}

According to the results of the demographic study, the mean age of the veterinarians who serve companion animals in Istanbul was determined as 42.4 years. In the United States, the average age is 44.3 years and is in parallel with the situation in Turkey (Data USA, 2018). In parallel with the average age in the study, $56 \%$ of veterinarians are between the ages of 41-50. The youngest clinic owner is 25 and the oldest clinic owner is 60 years old. $88.9 \%$ of veterinarians in Istanbul are married and $63.6 \%$ are male and $36.4 \%$ are female. In an another study conducted in Ankara in 2010, $71.9 \%$ of veterinarians were male and $28.1 \%$ were female (Aral et al., 2010). From this point of view, it is important that the rate of female veterinarians has increased.

When the universities graduated from the veterinarians in the clinics operating in Istanbul were examined, it was determined that the vast majority (77.3\%) were Istanbul University. Ankara University ranks second with $11.6 \%$ and Uludağ University ranks third with $5.8 \%$. According to this result, it is seen that those who graduated from Istanbul University In 
generally start their business life in Istanbul. In order to evaluate this more accurately, it is necessary to know from which cities those who receive education at Istanbul University come.

The average experience of veterinarians in the companion animal sector was 17.1 years. Considering that companion animal sector started to develop in our country in the mid-90s, it has been seen that the experience periods determined by the research are parallel to the development of the sector. In a previous study conducted in 56 clinics in Istanbul, Izmir, Konya and Aydın provinces, it was reported that the average duration of experience of veterinarians was 18.6 years (Mat et al., 2018) and shows parallelism with this study. Considering the distribution, $41.8 \%$ of veterinarians have $11-20$ years of experience and $30.2 \%$ of veterinarians have $20-30$ years of experience. The proportion of clinicians who are newly admitted to the profession and have up to 5 years of experience is $8.9 \%$. The least experienced veterinarian has been in the profession for 3 years and the most experienced veterinarian has been for 35 years.

When examined in terms of educational status, it was determined that the vast majority of veterinarians $(84.9 \%)$ were faculty graduates. Those with doctorate level education have $14.2 \%$ and those with academicians have $0.9 \%$.

In this study, the opinions of veterinarians about the faculties they graduated from and their communication status were also examined. According to the results, $16.9 \%$ of veterinarians consider their faculties to be at the top and $31.6 \%$ consider them to be below the middle. A total of $51.6 \%$ of veterinarians consider their faculties to be medium and below average. More than half (56.5\%) of the veterinarians state that they recommend their faculties, but $40.5 \%$ rarely communicate the faculty members and assistants of the faculties they graduated and $16.4 \%$ never communicate them. In this study, the opinions of veterinarians about the faculties they are educated and their communication status with the faculty members were examined in general due to the wide scope. Both the fact that more than half of the veterinarians do not see their faculties on top and that their communication levels with the faculty members are low despite the abundance of all kinds of communication channels in our age clearly reveals the necessity of evaluating these points on a faculty basis by conducting more detailed studies in the future.

All of the veterinarians participating in the study saw the establishment of new faculties in public universities as a negative development, while $1.8 \%$ of the veterinarians approached the establishment of veterinary faculties in foundation universities positively, while $2.2 \%$ stated that they remained undecided. It seems important from a professional point of view to conduct detailed studies on why veterinarians look positively at foundation universities while completely opposed to public universities and to question this issue.

According to results, $78.7 \%$ of the veterinarians stated that they wanted to work on companion animals before graduating from the faculty and $68 \%$ stated that they started working in the pet clinic after graduation. These values indicate that veterinarians chose to work in the pet clinic knowingly and by planning. However, since the vast majority of veterinarians in this study are educated in Istanbul, the issue of the effect of choosing this field and when it occurred should be determined by examining separately.

When the sectors that started the first job after graduation are examined, it is noteworthy that the pharmaceutical sector ranks second with $8.9 \%$, academician ranks third with $6.7 \%$ and the food sector ranks fourth with $4.0 \%$. The average period of starting the profession after graduation is 3.8 months. This period is of utmost importance especially in the unemployment problem. Accordingly, veterinarians can start working in clinics immediately after graduation. However, considering that the vast majority of clinician veterinarians have already wished to work in a companion animal clinic since the student period, it can be considered that not all veterinarians may be able to start work in such a short time. For this, it is also necessary to know about veterinarians working in other sectors.

When the initial earnings status after graduation was examined, $70.2 \%$ of veterinarians stated that they started their first job after graduation with the minimum wage determined by the chambers. The rate of those who start with a wage higher than the chambers' minimum wage is $29.8 \%$. At this point, it seems necessary to examine the start-up fees and the structures of the enterprises in detail with other studies. In these examinations, the analysis of which level of enterprises started with high wages and which level of enterprises with low wages will provide important results.

Almost all of the veterinarians (96.9\%) who participated in the study stated that they were generally satisfied with their professions. When the satisfaction status is examined in detail, it is seen that it is quite satisfied in scientific ( 8.0 points) and 
technical aspects (7.9 points) and satisfied in economic aspects (7.3 points). The average social score was found to be quite low and 5.3 out of 10 . $90.2 \%$ of the veterinarians who are satisfied with their professions stated that they can recommend veterinary medicine and $79.1 \%$ stated that they can recommend pet clinic. The rate of those who stated that they would not recommend companion animals as a field of study is only $4.0 \%$.

In terms of choice of profession, veterinarians stated that $68.9 \%$ preferred veterinary medicine for job satisfaction and $18.2 \%$ preferred it for profit. Those who are veterinarians to become entrepreneurs have $9.4 \%$ and those who choose for social status have $2.2 \%$. The most important criterion in the selection of pet clinic is the desire to become a pet clinician with $57.4 \%$. The economic reason is the second and third reasons with $24.4 \%$ and the love of pets with $16.0 \%$. In general, the vast majority of veterinarians stated that they would choose veterinary medicine again if they had to make a decision today. The rate of those who approach this question negatively is only $6.7 \%$.

The average daily working time of veterinarians is 10.5 hours and only $7.6 \%$ of veterinarians reported that they could continuously devote sufficient time to their private lives due to this long working time. The rate of veterinarians who never spend time in their private lives is determined as $33.3 \%$. This situation indicates that the fact that veterinarians cannot devote time to their social lives and environments together with the obligation to work individually and that the status of the profession in social life will need longer. In short, this should be seen as a professional problem rather than an individual problem.

Professions can be seen in a better position by society, not only by fulfilling the requirements of the profession they perform, but also by other social activities of colleagues. Therefore, it may be a longer time before veterinarians and the veterinary profession who cannot devote enough time to social life rank higher.

When the general situation of the profession is examined, it is determined that communication is generally weak. $57.7 \%$ of the veterinarians participating in the study stated that there is a weak solidarity between colleagues in their regions and $25.0 \%$ stated that there is no solidarity at all. The future status of veterinary medicine is seen as moderate with $40.9 \%$. Only $25.7 \%$ ( $13.3 \%$ good and $12.4 \%$ better) see the future positively.

Results show that $78.2 \%$ of the veterinarians participating in the study stated that they regularly participate in professional organizations and $21.8 \%$ stated that they do not participate. The most frequently attended organizations are organized by associations with $33 \%$ and companies with $29 \%$. In the third place are the organizations organized by the chambers with $22.7 \%$ and in the fourth place are the organizations organized by the universities with $15.3 \%$. The benefits of these organizations were also asked in the research and it was determined that the most important benefit with $50.3 \%$ contributed to vocational education. The rate of being considered as a tourist trip activity is $17.4 \%$ and the rate of being considered as contributing to socialization is $17.0 \%$. Experience gaining is fourth with $9.6 \%$ and commercial contribution is fifth with $5.7 \%$.

When the scientific and professional publications were examined, only $17.8 \%$ of the veterinarians participating in the research stated that they regularly follow scientific or professional publications. It is noteworthy that the majority of these publications are in English. In terms of the mostfollowed publications, The Veterinary Journal Elsevier ranked first with $38.5 \%$, Veterinary Clinician's Brief ranked second with $30.8 \%$, Turkish Veterinary Journal ranked third with $17.3 \%$ and Royal Canin Veterinary Focus ranked fourth with $8.0 \%$. Although the proportion of veterinarians who regularly follow scientific publications is not very high, it can be stated that scientific meetings are useful for veterinarians to renew themselves.

When the number of employees, which is one of the determinants of service quality, was examined, it was determined that 4.8 people worked in a clinic on average. While the minimum number of employees is 1 , the maximum number of employees is 25 . The average number of veterinarians working in clinics was 2.3 and the number of technicians was 0.8 . In addition, $69.8 \%$ of the clinics reported that they provided services by making visits outside the clinic through their staff.

When asked why clinics were preferred by patient owners, $66.7 \%$ of the veterinarians participating in the study stated that the criterion that patient owners attach the most importance to when choosing clinics was the reference. The closeness of the clinic is the second important criterion with $20.4 \%$, online research was the third important criterion with $9.3 \%$ and appearance is the fourth important criterion with $3.6 \%$.

The annual expenditure amounts of the patient owners are also examined in this research. At the end of the study, it was determined that the patient owners spent 2822 TL (400 USD) annually for cats and 
t4516 TL (641 USD) annually for dogs. According to a study conducted in 2012 among cat-dog owners in Istanbul, routine health practices (annual vaccinations, antiparasitic applications, etc.) have been reported to be around 600 TL for cats and 1000 TL for dogs each year (Onur, 2012). In a study conducted in 2014, it was stated that the average annual expenditure for cats was $1173 \mathrm{TL}$ and for dogs was 2013 TL (Demir and Uğurlu Koç, 2014). The increase amounts in recent years and the ratios between cat-dog expenditures are in parallel with the results of this study.

For the year 2020 the average monthly earnings of the veterinarians participating in the study were calculated as $17618 \mathrm{TL}$. In this study reported $86.7 \%$ of veterinarians an income of less than 30000 TL. According to the survey published by the European Federation of Veterinarians in 2018 (FVE, 2018), the average monthly income of veterinarians in Turkey is stated as 3000 Euros. Considering that the average annual Euro exchange rate for 2020 is 8.18 TL (The Central Bank of the Republic of Turkey, 2020) according to The Central Bank of the Republic of Turkey, monthly earnings are calculated as $24540 \mathrm{TL}$. Since FVE's surveys cover entire animal health industry it is understandable that there are differences in results.

When the rental expenses of the clinics are examined, it has been determined that the amount of rent paid is 9569 TL (1357 USD) on average per month. The vast majority of clinics, $73.7 \%$, pay rent up to $10000 \mathrm{TL}$ (1418 USD). The fact that almost all of the veterinary clinics in Istanbul (96.4\%) are tenants is considered an interesting issue to be evaluated. The study which was conducted in 2010 monthly amount of rent of the clinics was around 450 USD (Aral, 2010). This difference could come from the difference in economic sizes between İstanbul and Ankara.

The items that have the largest share in terms of income items are vaccination applications, operations, and treatments. These three practices account for $83.9 \%$ of the revenues of clinics. Similar to our findings according to study which was conducted in Hungary, in terms of source of income most important items were surgical operations vaccination applications (Ozsvari, 2014). The largest share in expense items is drug expenditures with a ratio of $23.9 \%$. Vaccination expenses are second with $22.9 \%$ and general expenses are third with $20.5 \%$. The rates here are important in terms of showing how much of the income and expenses of veterinarians in clinics are over their own medicine.

Since medical devices are important for clinics and require investment, this point has also been examined in detail in the research. As a result of the research, it was determined that all clinics have microscopic examination equipment, $95.0 \%$ have $X$ rays, $87.0 \%$ have blood analysers and $80.0 \%$ have urine analysers. It has been determined that the average value of medical devices owned by a clinic is 287422 TL (40769 USD). In addition, only $2.0 \%$ of clinics have rental devices. When the results are analysed, it is seen that the majority of the clinics have microscopic examination equipment, X-ray, blood analyser and urine analyser, which are the basic laboratory equipment. Further examination equipment such as ECG, CR and ultrasound are also available in almost $50 \%$ of the clinics. The reasons for the presence of such a variety of equipment in clinics in the presence of analysis laboratories should be examined separately. In addition, it is also important to know how long the equipment investment turns into profit, how necessary the investment is, the effective use of the equipment, how long it is renewed and the ratio of the clinic in income and expenses. Determining the average value calculated in the study and how much equipment can be obtained may also indicate the level of average equipment ownership of clinics.

In order to examine the collection and payment status of the clinics, questions were directed to the veterinarians in this direction. According to results $73.0 \%$ of the veterinarians who participated in the study stated that they generally collected the fee they demanded for the service they provided, and $12.0 \%$ stated that they had difficulty in collecting. With the research, the average uncollectible annual receivable of a clinic was determined as 28444 TL (4034 USD). Considering that there are 749 clinics in Istanbul, it is noteworthy that the sector has a large commercial loss of approximately 21 million TL (approx. 3 million USD). Examining this problem in detail and determining its causes will prevent major financial problems in the sector in the long term. When examined in terms of collection and payment, the use of credit card stands out. The most common payment method used by clinics is credit card with $47.2 \%$ and the collection method is credit card with $73.9 \%$.

\section{Conclusion}

In the pet sector, veterinary clinics, which have started to develop since the 1990s, have an important place as one of the most basic components of the sector due to both employment opportunities and the turnover and added value they produce. The number of clinics -also due to the opening of new faculties- is increasing very rapidly, which makes the competition harder.

Although veterinarians generally state that they 
happy with their profession, being in a socially negative situation and lack of communication both with the faculties they graduated from and among themselves may have a negative impact on the profession in the long term.

The fact that the pet sector has developed considerably in parallel with the general education level in our country and despite the increase in opportunities, problems such as the low rate of women, working more than 10 hours a day, opening a large number of clinics, and experiencing a high amount of collection shortage clearly reveal that communication management and business knowledge are required in addition to professional knowledge to have a successful clinic today (in 2021). Although management in the veterinary profession is not a very focused area in the educational process, development in this field has always been very important for success (Draper and Uhlenhopp, 2002). In the current situation in Turkey, in spite of providing adequate education in faculties, studies should be carried out for students to graduate in a more equipped way in the future, veterinarians, educational institutions and professional organizations should develop detailed and long-term plans.

\section{References}

APPA - American Pet Products Association (2020). Pet industry market size \& ownership statistics. Retrieved from: https:// www.americanpetproducts.org/ press_industrytrends.asp [Accessed 2 June 2021].

Aral, Y., Cevger, Y., Pınar, D., \& Aydın, E. (2010). Ankara ili evcil hayvan veteriner kliniklerinin yönetimsel ve ekonomik açıdan değerlendirilmesi. Kafkas Üniversitesi Veteriner Fakültesi Dergisi, 16(3), 503508.

Data USA (2018). Veterinarians, age by gender. Retrieved from: https://datausa.io/profile/soc/ veterinarians\#demographics [Accessed 1 June 2021].

Demir, E. (2017). Istatistik Ders Notları. Ankara. Turkey: Ankara Üniversitesi Eğitim Bilimleri Fakültesi, 14.

Demir, P., \& Uğurlu Koç, A. (2014). Pet hayvan (kediköpek) sahiplerinin veteriner kliniklerine ilişkin beklentileri. İstanbul Üniversitesi Veteriner Fakültesi Dergisi, 40(2), 168-175.

Draper, D. D., \& Uhlenhopp, E. K. (2002). A Veterinary business curriculum model. Journal of Veterinary Medical Education, 29, 73-74.

Evrim, M. ve Güneş, H. (2000). Biyometri. İstanbul, Türkiye: Üniversitesi Veteriner Fakültesi Yayını, Ders
Notu No: 113

FEDIAF-The European Pet Food Industry (2016). Annual report 2016. Retrieved from: https://fediaf.org/ images/FEDIAF_Annual_Report__ 2016_cor.pdf [Accessed 2 June 2021].

FEDIAF-The European Pet Food Industry (2020). Annual report 2020. Retrieved from: https://fediaf.org/ images/FEDIAF_Annual_Report__ 2020_cor.pdf [Accessed 31 May 2021].

FVE-Federation of Veterinarians of Europe (2018). Vet survey 2018. Retrieved from: http://fvesurvey.com/ download/148/ [Accessed 29 May 2021].

Global Market Insights (2020). Pet care market. Retrieved from: https://www.gminsights. com/ industry-analysis/pet-caremarket?

utm_source=globenewswire.com\&utm_medium=re ferral\&utm_campaign=Paid_globenewswire [Accessed 29 May 2021].

Harvard Medical School (2014). Why having a pet is good for your health. Retrieved from: https:// www.health.harvard.edu/staying-healthy/whyhaving-a-pet-is-good-for-your-health [Accessed 27 May2021].

HEKTAŞ (2018). Rakamlarla Pet sektörü: 2 milyar dolarlık pazarda HEKTAŞ hamlesi [Basın bülteni, April 25]. Retrieved from: https://www.dunya.com/ sirketler/2-milyar-dolarlik-pazarda-hektas-hamlesihaberi-413047 [Accessed 21 May 2021].

Hesselmar, B., Aberg, N., Aberg, B., Eriksson, B., \& Björkstén, B. (1999). Does early exposure to cat or dog protect against later allergy development? Clinical \& Experimental Allergy Journal, 29(5), 611617.

Kaygısız, F., \& Akdağ, F. (2004). İstanbul ilindeki veteriner klinik işletmelerinin teknik ve mali yapıları ile işletmecilik sorunları üzerine bir araştırma. İstanbul Üniversitesi Veteriner Fakültesi Dergisi, 30 (2), 63-78.

Mat, B., Çevrimli, M. B., \& Günlü, A. (2018). Current problems and suggestions for the marketing and use of medical products in the field of animal health and breeding. Eurasian Journal of Veterinary Sciences, 34, 4, 233-241.

Onur, E. (2012). Socio-economical parameters of cat and dog ownership in Istanbul (PhD. Thesis). Istanbul University, Istanbul, Turkey.

Orhunbilge, N. (2000). Örnekleme yöntemleri ve hipotez testleri. İstanbul, Türkiye: Avcıol Basım Yayın, 4.

Ozsvari, L. (2014, October 22 ). Practise management in the Hungarian small animal veterinary clinics. 
Balaban and Güneş 2021 / Journal of Istanbul Veterinary Sciences. Volume 5, Issue 2, pp: 72-86

Paper presented at the New Trends in Management in the 21th Century Conference,, Czestochowa, Poland.

Ratschen, E., Shoesmith, E., Shahab, L., Silva, K., Kale, D., Toner, P., Reeve, C., \& Mills, D. S. (2020). Covid19 lockdown phase in the UK: Investigating links with mental health and loneliness. PLOS ONE 15 (9): e0239397.

Ministry of Agriculture and Forestry (2021a). Tarım ve Orman Bakanlığı 2020 faaliyet raporu. Retrieved from: https://www.tarimorman.gov.tr/Konular/Plan -Program-Ve-Faaliyet-Raporlari/faaliyet-raporlar\% c4\%b1 [Accessed 07 June 2021].

Ministry of Agriculture and Forestry (2021b). Veteriner hizmetleri. Retrieved from: https:// www.tarimorman.gov.tr/ Konular/Veteriner-
Hizmetleri/Serbest-Veterinerlik-Ve-VeterinerLaboratuvarlari [Accessed 20 May 2021].

The Central Bank of the Republic of Turkey (2020). Türk Lirası yükümlülükler için tesis edilen döviz cinsinden zorunlu karşılık tutarlarının hesaplanmasında esas alınacak ortalama döviz alıs kurları, 3. Retrieved from: https://www.tcmb.gov.tr/wps/wcm/connect/ TR/TCMB+TR/Main+Menu/Istatistikler/

Bankacilik+Verileri/Zorunlu+Karsiliklar/ [Accessed 20 May 2021].

Vidovic, V., Stetic, V. V., \& Bratko, D. (1999). Pet ownership, type of pet and socio-emotional development of school children. Anthrozoos A Multidisciplinary Journal of the Interactions of People \& Animals, 12, 211-217. 